\section{Environmental advice}

Washington

SENIOR executives from a number of leading US companies and a handful of representatives from environmentalist pressure groups have been appointed to a new think-tank to help develop US environmental policy. The President's Commission on Environmental Quality reflects President George Bush's belief that environmental problems are best tackled by voluntary cooperation between environmentalist groups and polluters, rather than by strict regulations passed down from government - a view contested by many environmentalist activists. The group's main focus will be on finding ways to solve pollution problems while minimizing the financial burden faced by industry, but its members have been given a reasonably free rein to set their own agenda.

\section{Overkill at Stanford?}

\section{Washington}

Anxious to reestablish its image as a responsible guardian of public funds, Stanford University last week unveiled a new system of accounting for the indirect costs of federal research grants.

The reforms aim to avoid the inclusion of inappropriate items under indirect costs (such as the well-publicized yacht and antique commode) by setting up separate accounts to handle these unallowable costs.

Representative John Dingell, whose House of Representatives subcommittee investigation uncovered the irregularities in Stanford's accounts, has already expressed scepticism over the reforms. But an independent panel chaired by Bobby Inman, a former deputy director of the Central Intelligence Ágency, believes Stanford may now have tried too hard to appease its congressional critics. "The accounting tail may well now wag the research dog," they write, in response to the proposed reforms.

P.A

\section{Fetal tissue research} Washington

THE House of Representatives voted last week to overturn the US Administration's ban on using federal funds to support research on tissue from human fetuses. But the 274:144 vote fell just short of the two-thirds majority needed to override an expected presidential veto of the National Institutes of Health (NIH) authorization bill, which carries the fetal tissue language. Since its enforcement in 1988 , the fetal tissue research ban has been a thorn in the side of NIH. The long delay in appointing an NIH director after James Wyngaarden's departure in 1989 is attributed in part to the difficulty in finding a candidate prepared to agree, at least in public, with the Administration.

P.A.

\title{
It's official: no more shuttles
}

\section{Washington}

BARRING a repeat of the 1986 Challenger accident, no more US space shuttles will be built. Speaking at Vandenburgh Air Force Base in California last week, Vice President Dan Quayle signalled publicly for the first time that the US Administration intends to wind down the troubled shuttle programme, and rely on a new generation of unmanned launchers to launch future satellites.

National Aeronautics and Space Administration (NASA) officials are said to have been seeking funds to add to the current fleet of four shuttles, and to build on shuttle technology to develop future launch vehicles. Quayle said the existing four craft would continue to be used into the next century, but he indicated that the shuttle's role as a 'cargo carrier' to deliver satellites into orbit was over: "It makes no sense to use shuttle astronauts unless we absolutely have to." Restrictions put in place after the Challenger disaster already ban the shuttles from WEATHER SATELLITES

\section{Washington
US National}

US National Aeronautics and Space Administration (NASA) deputy administrator James Thompson found himself in an impossible, but familiar, situation last week: before a group of angry congressmen, defending NASA's role in a project that is massively over budget, badly behind schedule and beset with technical difficulties.

Two House subcommittees were trying to untangle the factors that led to the current fiasco in the GOES-NEXT programme. This series of five geostationary weather satellites designed for the $\mathrm{Na}$ tional Oceanic and Atmospheric Administration (NOAA) is at least three years behind schedule and more than $\$ 500$ million over budget (see Nature 352, 97; 11 July 1991). The blame, judging by last week's hearing, lies largely with NASA, which hired contractors to build the satellites.

According to Howard Wolpe (Democrat, Michigan), chairman of the investigations subcommittee, senior NASA officials are even now making "deceptive and misleading" statements about the GOES-NEXT programme. Thompson testified last week that a wiring problem with the first satellite's imager should be resolved within four months, but Wolpe's aides say that NASA's own programme manager has informed them that this will take between six and nine months.

Wolpe also produced documents at last week's hearing showing that NASA had carrying commercial payloads.

Quayle said the United States would develop a new National Launch System, comprising a range of unmanned launchers, some of which could also launch manned missions. This programme will involve NASA and the Department of Defense, but it is not yet clear exactly what Quayle and the other members of the National Space Council have in mind. John Logsdon, a space policy analyst at George Washington University, expects some of the system's individual components to become apparent by the time of next year's presidential budget request.

Quayle's comments came shortly after yet another delayed space shuttle launch. The shuttle Atlantis was due to take off carrying a Tracking Data Relay Satellite on 23 July, but the failure of a computer controlling one of the craft's main engines has now put the launch back to the end of this week at the earliest.

Peter Aldhous

\section{for GOES-NEXT}

refused to convert the GOES-NEXT contracts to a fixed-price agreement in 1988 - a move that would have saved some $\$ 500$ million in cost overruns despite the willingness of both NOAA and the contractors to do so.

Thompson said he was confident that the first GOES-NEXT satellite, originally planned for 1989 , will be launched by late 1992 , providing coverage at least as good as the existing GOES-7, which will begin to drift out of position around that time.

But Wolpe's staff believe NASA's optimism over the GOES-NEXT schedule is unrealistic. NOAA has yet to make a firm decision on how to fill the gap in case of further GOES-NEXT delays, but the favoured option seems to be negotiating with the European weather satellite agency Eumetsat to move the Meteosat-3 satellite, already over the Atlantic, further westwards to give full coverage of the United States. The alternative, borrowing a satellite now being built by the Hughes Aircraft Corporation for the Japanese weather service, but not needed by them until 1994, involves the added risk and expense of a satellite launch, says NOAA assistant administrator Thomas Pyke. He adds that NOAA is now holding discussions with NASA to make the space agency responsible for development costs in future weather satellite programmes, preventing a repeat of the GOES-NEXT cost overruns from eroding NOAA's limited budget.

Peter Aldhous 